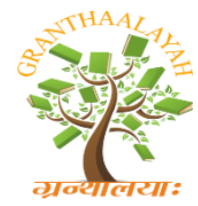

$$
\begin{aligned}
& \text { INTERNATIONAL JOURNAL OF RESEARCH - } \\
& \text { GRANTHAALAYAH } \\
& \text { A knowledge Repository }
\end{aligned}
$$

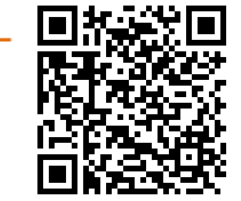

Management

\title{
SECTORAL ANALYSIS OF BANKS ON TRENDS OF OPENING ACCOUNTS FOR PRADHAN MANTRI JAN DHAN YOJNA PHASE I (PMJDY)
}

\author{
Prof Trilok Nath Shukla ${ }^{* 1}$ \\ *1 Associate Professor \& Vice Principal, Bhavan's Centre for Communication \& Management, \\ Bhartiya Vidya Bhavan, Bhubneswar, India
}

DOI: https://doi.org/10.29121/granthaalayah.v5.i1.2017.1734

\begin{abstract}
Most recently a national mission on financial inclusion called "PRADHAN MANTRI JAN DHAN YOJANA" was launched on the $28^{\text {th }}$ of August 2014. Under the direct supervision of the Indian Prime Minister and the Department of Financial Services, Ministry of Finance, the objective of this mission is to enroll over 70 million households and open their bank accounts along with providing them as a first step a RuPay debit card with a Rs. 1,00,000/- accident cover. In the due course of time the plan is to also cover these account holders with insurance and pension products. About $60 \%$ of the population in India does not have access to a bank account. PMJDY aims at providing bank account to single household above the age of 10 years who do not have bank account and will be opened with zero balance. The household opening the account will be benefited with one lakh accidental cover and Thirty Thousand life cover without premium. People opening account under this scheme will also avail overdraft facility up to five thousand from the bank after satisfactory conduct of the account for 6 months.

In this paper the trends of opening account in different sectors of banks like Pubic sector, private sector and regional rural banks has been studied.

Keywords: Pradhan Mantri Jan Dhan Yojana; Reserve Bank of India; Financial Inclusion; No Frills Account; Inclusive Banking.

Cite This Article: Prof Trilok Nath Shukla. (2017). "SECTORAL ANALYSIS OF BANKS ON TRENDS OF OPENING ACCOUNTS FOR PRADHAN MANTRI JAN DHAN YOJNA PHASE I (PMJDY)." International Journal of Research - Granthaalayah, 5(1), 183-197. https://doi.org/10.29121/granthaalayah.v5.i1.2017.1734.
\end{abstract}

\section{Introduction}

In order to increase outreach of Banking Services in every nook and corner of the country, various initiatives were taken by RBI/ GOI after Nationalization of Banks including Expansion of Branch network, Establishment of Cooperative Institutions, RRBs, Introduction of Priority 
Sector lending, Lead Bank Scheme, Formation of SHGs, Govt. sponsored Schemes etc. It has also been emphasized by the RBI for deepening and widening the outreach of Financial Services to cover large segment of the rural \& poor sections of population.. With a view to boost up the outreach Programme to provide Banking services and products in every villages of the country, implementation of Financial Inclusion Plan (FIP) was undertaken by Banks on priority basis. Various modes and models were adopted by Banks to cover the allotted villages to provide banking services in the villages under a time bound plan. .On realizing the fact that still sizeable population has not been brought into mainstream of Banking, the GOI decided to ensure coverage of all households of the country by adopting a planned approach. This followed the launch of a new holistic scheme named as "Pradhan Mantri Jan Dhan Yojana (PMJDY) "on 28.08.2014 with basic objective of achieving inclusive growth in Mission Mode.

In order to reduce the degree of "financial untouchability", and achieve the mega financial inclusion plan with the objective of covering all households in the country with banking facilities along with inbuilt insurance coverage, the "Pradhan Mantri Jan-Dhan Yojana" has been flagged off by the Government which, if effectively implemented, shall accelerate growth, fight poverty effectively and financially empower each individual of Indian economy. PMJDY is a National Mission on Financial Inclusion encompassing an integrated approach to bring about comprehensive financial inclusion of all the households in the country. The plan envisages universal access to banking facilities with at least one basic bank account for every household, a strong financial literacy drive, access to credit, insurance and pension facility. In addition, the beneficiaries would get RuPay Debit card having inbuilt accident insurance cover of Rs.100000/. The plan also envisages channeling all Government benefits (from Centre / State / Local Body) to the bank accounts of the beneficiaries and pushing the Direct Benefits Transfer (DBT) scheme of the Union Government.

PMJDY or Pradhan Mantri Jan Dhan Yojana is a nationwide scheme launched by Indian government in August 2014 and its core lies at the development philosophy of Sab Ka Sath Sab Ka Vikas. The basic objective of "Pradhan Mantri Jan-Dhan Yojana (PMJDY)" is ensuring access to various financial services like availability of basic savings bank account, access to need based credit, remittances facility, insurance and pension to the excluded sections i.e. weaker sections \& low income groups. This deep penetration at affordable cost is possible only with effective use of technology. Under the scheme, all 6,00,000 villages will be mapped to the service area of each bank and at least one fixed point banking outlet will cater to every 1000 to 1500 households, known as ,sub service area ${ }^{e e}$ or SSA. The SSA ${ }^{\text {ee }}$ re then serviced through a combination of bank branches and fixed point business correspondents or bank mitrs.

\section{Review of Literature}

Artta Bandhu Jena (2015) focused on financial inclusion is very vital towards economic development and well-structured financial system of a country. PMJDY is an ambitious financial scheme which will provide a host of benefits including a bank account, insurance and a debit card to non-bank account holders in India. PMJDYs target is to open 7.5 crore bank accounts by January, 2015. 
Barhate and Jagtap (2014) discovered in their study financial inclusion, strategy of PMJDY and issues related to the success of the scheme. They concluded that every new thing requires determination and attitude towards success path. Besides that to withstand the heat of economic down surge and fight poverty, the Jan Dhan Yojana is good mechanism.

Paramasivan and Ganeshkumar (2013) have revealed that branch density has significant impact on financial inclusion. It is not possible to achieve financial inclusion only by creating investment awareness, without significantly improving the investment opportunities in India. Rajanikanta Khuntia (2014) delivered that in every household within the grasp of the banking system there has been an ongoing process started a decade ago. In order to reduce the degree of "financial untouchability" the new government has come up with a big bang action plan which is popularly known as "Pradhan Mantri Jan-Dhan Yojana". It's a mega financial inclusion plan with the objective of covering all households in the country with banking facilities along with inbuilt insurance coverage.

Shetty and Deokar (2014) discussed in their findings that "Pradhan Mantri Jan Dhan Yojana" is not a new programme but there were various programmes initiated by RBI and Ministry of Finance, but due to lack of co-ordination among people, government and RBI, the objectives of all those programme have not been achieved till now. Formulation of programme is not sufficient for conversion of dreams into reality, but this requires effective and transparent implementation of that programme at the ground level with the coordination of government, bank and the general public.

\section{Objective of Study}

In this paper the trends of opening account in different sectors of banks like Pubic sector, private sector and regional rural banks has been studied.

\section{Research Methodology}

- Type of Research: This is an analytical and exploratory research based on real data obtained from the various banks, Ministry of Finance (MoF), Jan Dhan Project Report etc. All this will help us in getting a true idea about the various Pros and Cons of this flagship project. It will also help in analyzing various factors and gaps present in implementation of the project.

- Type of Data: This is the primary data collected from all the banks by the Department of Financial services, Ministry of Finance.

- Research Design:

$>$ Calculation: The entire project is largely depending on the Microsoft Excel's Calculations.

- Software's used for data analysis: I have mainly used Microsoft Word and Excel in the project. 


\section{Trends of Deposits in Different Sector of Banks}

\subsection{Public Sector Banks}

\begin{tabular}{|c|c|c|c|c|c|c|}
\hline $\begin{array}{l}\text { NAME OF } \\
\text { BANK }\end{array}$ & RURAL & URBAN & ACCOUNTS & $\begin{array}{l}\text { RUPAY } \\
\text { DEBIT } \\
\text { CARDS }\end{array}$ & $\begin{array}{l}\text { BALANCE } \\
\text { IN } \\
\text { ACCOUNTS }\end{array}$ & $\begin{array}{c}\text { NO OF } \\
\text { ACCOUNTS } \\
\text { WITH ZERO } \\
\text { BALANCE }\end{array}$ \\
\hline $\begin{array}{l}\text { Bhartiya } \\
\text { Mahila Bank }\end{array}$ & 0 & 0.59 & 0.59 & 0.59 & 509.83 & 0.23 \\
\hline $\begin{array}{l}\text { State Bank of } \\
\text { Travancore }\end{array}$ & 0.34 & 2.91 & 3.25 & 2.72 & 12417 & 0.4 \\
\hline $\begin{array}{l}\text { State Bank of } \\
\text { Mysore }\end{array}$ & 5.72 & 1.95 & 7.67 & 7.23 & 336.64 & 7.29 \\
\hline $\begin{array}{ll}\text { IDBI } & \text { Bank } \\
\text { Ltd } & \end{array}$ & 4.49 & 4.09 & 8.58 & 8.34 & 2502.37 & 6.73 \\
\hline $\begin{array}{l}\text { State Bank of } \\
\text { Patiala }\end{array}$ & 3.78 & 7.07 & 10.85 & 10.4 & 23234 & 7.53 \\
\hline Vijaya Bank & 6.8 & 4.71 & 11.51 & 11.38 & 3926.01 & 7.26 \\
\hline $\begin{array}{l}\text { Punjab \& } \\
\text { Sind Bank }\end{array}$ & 7.76 & 4.18 & 11.94 & 11.09 & 41747.97 & 6.38 \\
\hline Andhra Bank & 10.58 & 6.55 & 17.13 & 16.93 & 6594.67 & 11.97 \\
\hline $\begin{array}{l}\text { Bank of } \\
\text { Maharashtra }\end{array}$ & 12.04 & 5.6 & 17.65 & 17.16 & 18422.14 & 11.39 \\
\hline $\begin{array}{l}\text { Corporation } \\
\text { Bank }\end{array}$ & 9.28 & 9.37 & 18.65 & 17.45 & 27924.71 & 6.98 \\
\hline $\begin{array}{l}\text { Oriental } \\
\text { Bank of } \\
\text { Commerce }\end{array}$ & 12.23 & 8.67 & 20.9 & 19.98 & 88539.18 & 7.99 \\
\hline $\begin{array}{l}\text { State Bank of } \\
\text { Bikaner and } \\
\text { Jaipur }\end{array}$ & 9.86 & 12.29 & 22.15 & 18.79 & 46903.2 & 12.23 \\
\hline Dena Bank & 15.45 & 7.79 & 23.25 & 22.18 & 13949 & 16.02 \\
\hline $\begin{array}{l}\text { State Bank of } \\
\text { Hyderabad }\end{array}$ & 8.31 & 15.43 & 23.74 & 22.2 & 10201.91 & 17.45 \\
\hline $\begin{array}{l}\text { Allahabad } \\
\text { Bank }\end{array}$ & 16.82 & 7.29 & 24.11 & 23.56 & 6514.51 & 18.28 \\
\hline Indian bank & 15.32 & 9.01 & 24.33 & 23.13 & 11755.32 & 15.44 \\
\hline $\begin{array}{l}\text { Indian } \\
\text { Overseas } \\
\text { Bank }\end{array}$ & 9.76 & 18.69 & 28.45 & 26.85 & 1256.61 & 24.17 \\
\hline $\begin{array}{l}\text { United Bank } \\
\text { Of India }\end{array}$ & 18.29 & 13.66 & 31.95 & 29.69 & 74343.38 & 11.18 \\
\hline Syndicate & 21.22 & 10.96 & 32.18 & 30.64 & 26966.12 & 21.28 \\
\hline
\end{tabular}




\begin{tabular}{|l|l|l|l|l|l|l|}
\hline Bank & & & & & & \\
\hline Uco Bank & 18.66 & 19.47 & 38.14 & 34.1 & 39918 & 22.28 \\
\hline $\begin{array}{l}\text { Union Bank } \\
\text { Of India }\end{array}$ & 30.71 & 9.79 & 40.49 & 38.34 & 22291.35 & 27.67 \\
\hline $\begin{array}{l}\text { Central bank } \\
\text { of India }\end{array}$ & 40.27 & 11.97 & 52.24 & 46.5 & 20192.63 & 37.63 \\
\hline $\begin{array}{l}\text { Bank Of } \\
\text { India }\end{array}$ & 23.81 & 33.98 & 57.79 & 56.29 & 27557 & 38.72 \\
\hline Canara Bank & 40.8 & 19.58 & 60.38 & 60.38 & 73829.88 & 24.74 \\
\hline $\begin{array}{l}\text { Bank of } \\
\text { Baroda }\end{array}$ & 27.58 & 38.93 & 66.51 & 64.52 & 64108 & 34.8 \\
\hline $\begin{array}{l}\text { Punjab } \\
\text { National } \\
\text { Bank }\end{array}$ & 57.96 & 13.77 & 71.73 & 62.71 & 77694.62 & 55.56 \\
\hline $\begin{array}{l}\text { State Bank of } \\
\text { India }\end{array}$ & 105.14 & 153.19 & 258.33 & 229.15 & 73827 & 203.81 \\
\hline Total & $\mathbf{5 3 2 . 9 8}$ & $\mathbf{4 5 1 . 4 9}$ & $\mathbf{9 8 4 . 4 9}$ & $\mathbf{9 1 2 . 3}$ & $\mathbf{8 1 7 4 6 3 . 0 5}$ & $\mathbf{6 5 5 . 4 1}$ \\
\hline
\end{tabular}

\section{Chart 1 URBAN Vs. RURAL ACCOUNTS}

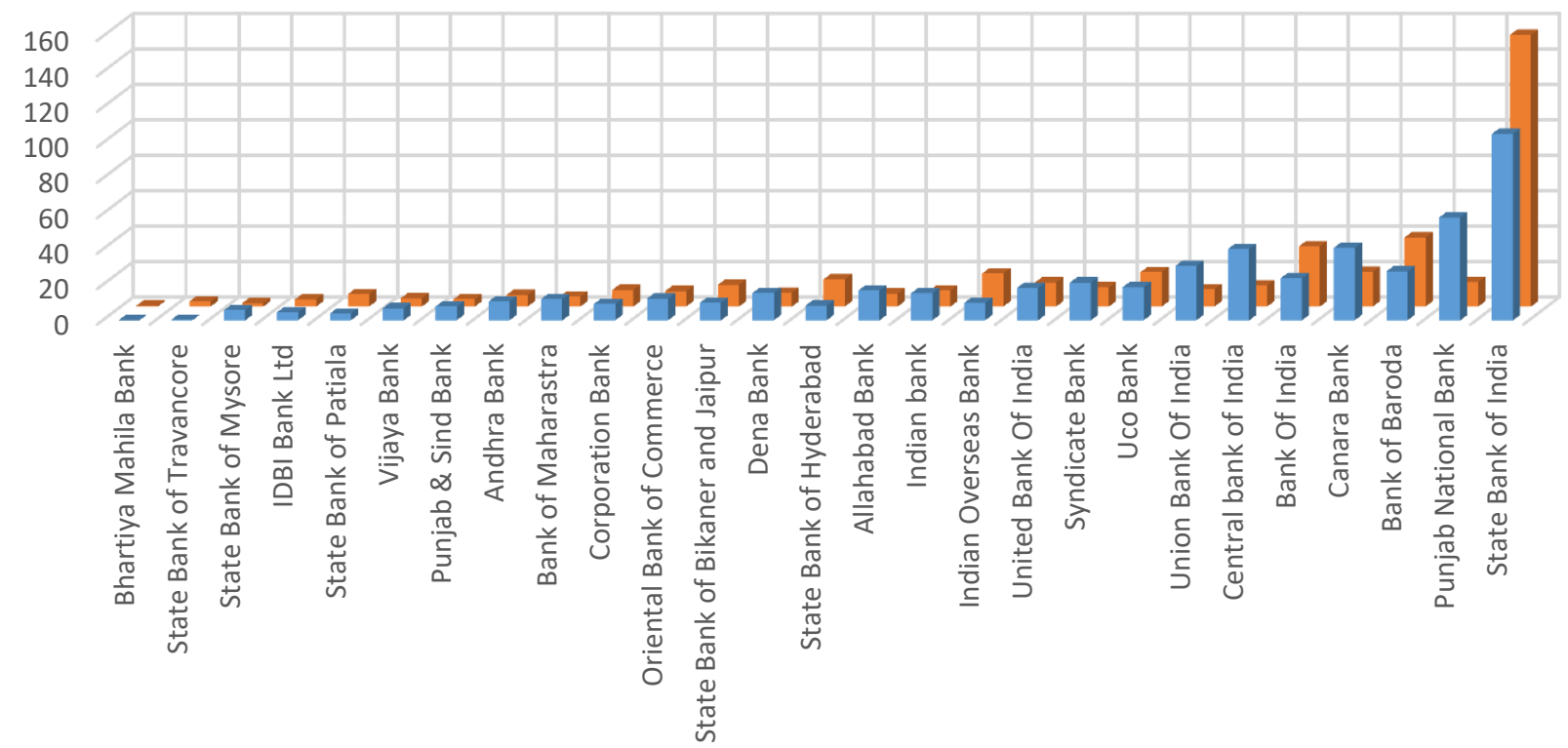


- This graph shows the distribution of urban and rural accounts opened by various public sector banks in phase-I.

- The banks have been arranged in an increasing account opening across various public sector banks during Phase-I.

- Many banks have opened more urban accounts than rural accounts.

- The best performer is State Bank of India (SBI) which has the maximum coverage all over India.

- It should also be noted that the banks that have been the least performers are basically new banks or banks which have less market coverage.

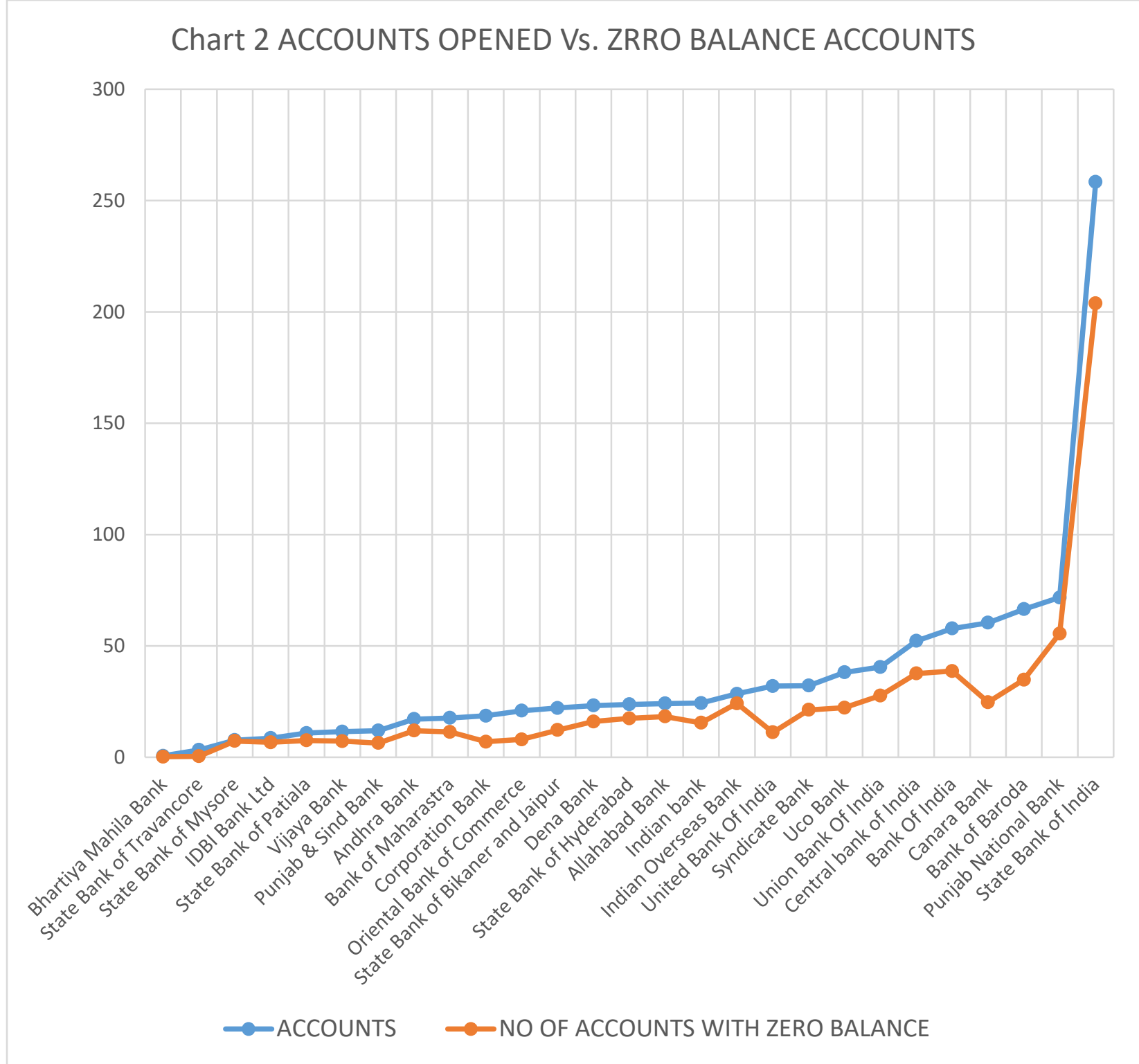

- This graph shows the distribution of accounts opened and the trend of zero balance accounts across various respective banks. 
- The banks have been arranged in an increasing account opening across various public sector banks during Phase-I.

- Canara bank have been the most successful bank in curbing the problem of zero balance accounts because of their proactive measures of interacting with various Panchayat and roping in various NGO's into the program, which has resulted for being a success story in PMJDY mission.

- Most banks have been able to curb the problem of zero balance accounts to some extent.

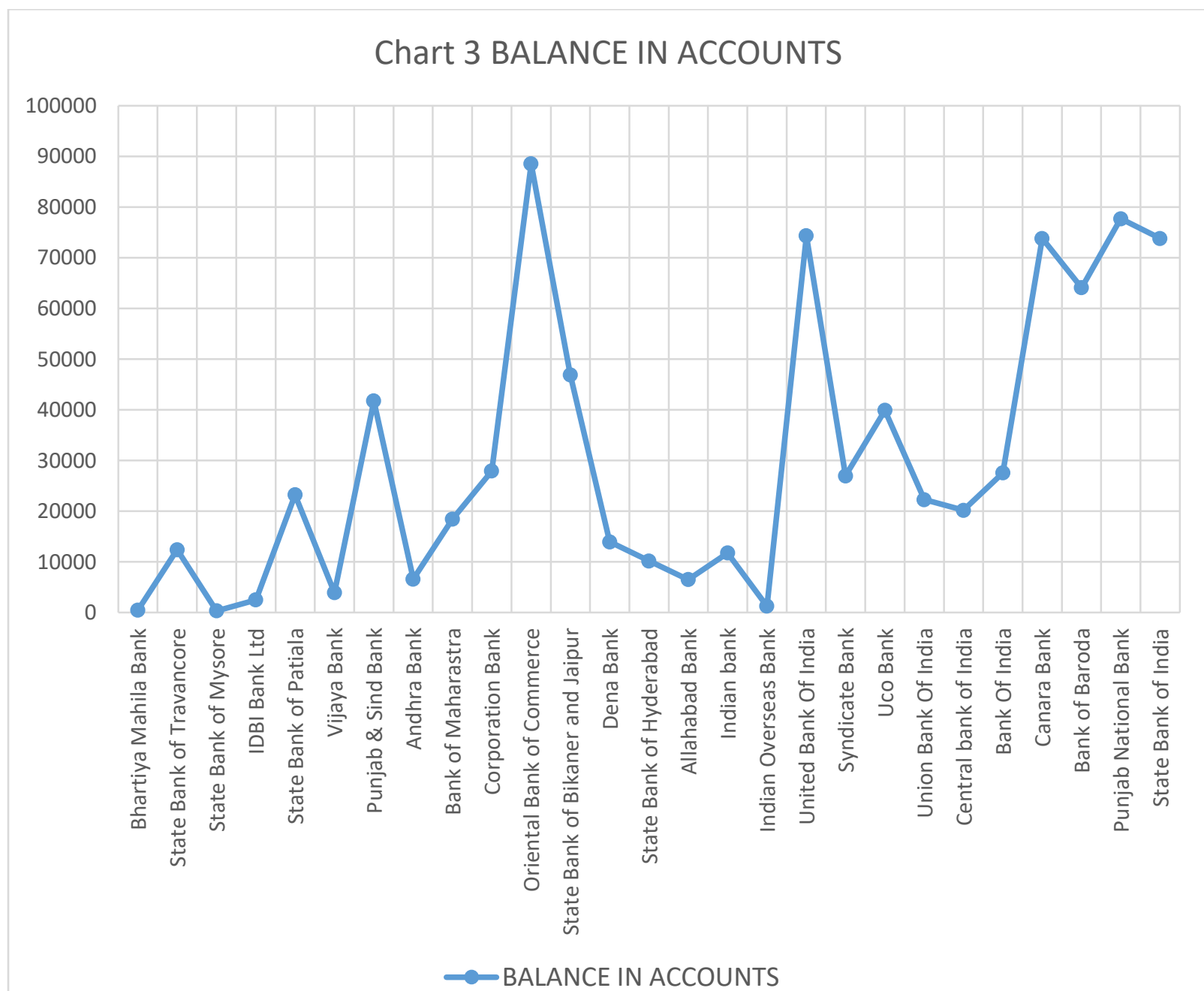

- This graph shows the deposits made across various banks against the account opened during Phase-I.

- The banks have been arranged in an increasing account opening across various public sector banks during Phase-I.

- Oriental Bank of Commerce (OBC) is the best performing bank in this aspect.

- Canara bank with its proactive measures of reducing the zero balance accounts have been able to have high deposits, whereas even if SBI had maximum account opening it has not been able to have maximum deposits.

- Another important point should be noted that the banks with high rural account opening have had maximum deposits during Phase-I. 


\subsection{Private Sector Banks}

\section{Table 2: BANKWISE ACCOUNT OPENED DETAIL REPORT AS ON 31.01.2015}

\begin{tabular}{|l|l|l|l|l|l|l|}
\hline $\begin{array}{l}\text { NAME OF } \\
\text { BANK }\end{array}$ & RURAL & URBAN & ACCOUNTS & $\begin{array}{c}\text { RUPAY } \\
\text { DEBIT } \\
\text { CARDS }\end{array}$ & $\begin{array}{c}\text { BALANCE } \\
\text { IN } \\
\text { ACCOUNTS }\end{array}$ & $\begin{array}{c}\text { NO OF } \\
\text { ACCOUNTS } \\
\text { BALANCE }\end{array}$ \\
\hline Yes Bank & 0.05 & 0.03 & 0.09 & 0 & 26.69 & 0.08 \\
\hline $\begin{array}{l}\text { Lakshmi } \\
\text { Vilas Bank }\end{array}$ & 0.15 & 0.46 & 0.61 & 0.2 & 146.09 & 0.24 \\
\hline $\begin{array}{l}\text { City Union } \\
\text { Bank Ltd }\end{array}$ & 0.12 & 0.57 & 0.69 & 0 & 462.43 & 0.37 \\
\hline $\begin{array}{l}\text { Ratnakar } \\
\text { Bank }\end{array}$ & 0.6 & 0.3 & 0.9 & 0.9 & 111.76 & 0.51 \\
\hline $\begin{array}{l}\text { Karur Vaisya } \\
\text { Bank }\end{array}$ & 0.07 & 0.86 & 0.93 & 0.9 & 285.59 & 0.64 \\
\hline $\begin{array}{l}\text { South Indian } \\
\text { Bank }\end{array}$ & 0.16 & 0.79 & 0.95 & 0.51 & 586.5 & 0.48 \\
\hline $\begin{array}{l}\text { Kotak } \\
\text { Mahindra } \\
\text { Bank }\end{array}$ & 0.55 & 0.45 & 1 & 0.9 & 310.46 & 0.85 \\
\hline $\begin{array}{l}\text { Indusind } \\
\text { Bank }\end{array}$ & 0.15 & 1.24 & 1.39 & 1.37 & 444.07 & 0.71 \\
\hline Federal Bank & 1.76 & 0.49 & 2.25 & 2.16 & 9534.45 & 1.23 \\
\hline Axis Bank & 0.99 & 3.36 & 4.36 & 4.21 & 2006.24 & 3.32 \\
\hline $\begin{array}{l}\text { Jammu and } \\
\text { Kashmir } \\
\text { Bank }\end{array}$ & 8.12 & 0.99 & 9.11 & 5.03 & 9749.35 & 6.6 \\
\hline HDFC Bank & 1.72 & 7.7 & 9.42 & 9.41 & 35066.29 & 5.81 \\
\hline $\begin{array}{l}\text { ICICI } \\
\text { Total }\end{array}$ & $\mathbf{3 2 . 2 7}$ & $\mathbf{2 0 . 1}$ & $\mathbf{5 2 . 3 9}$ & $\mathbf{4 5 . 9 2}$ & $\mathbf{7 2 5 5 1 . 5}$ & $\mathbf{2 9 . 9 6}$ \\
\hline
\end{tabular}




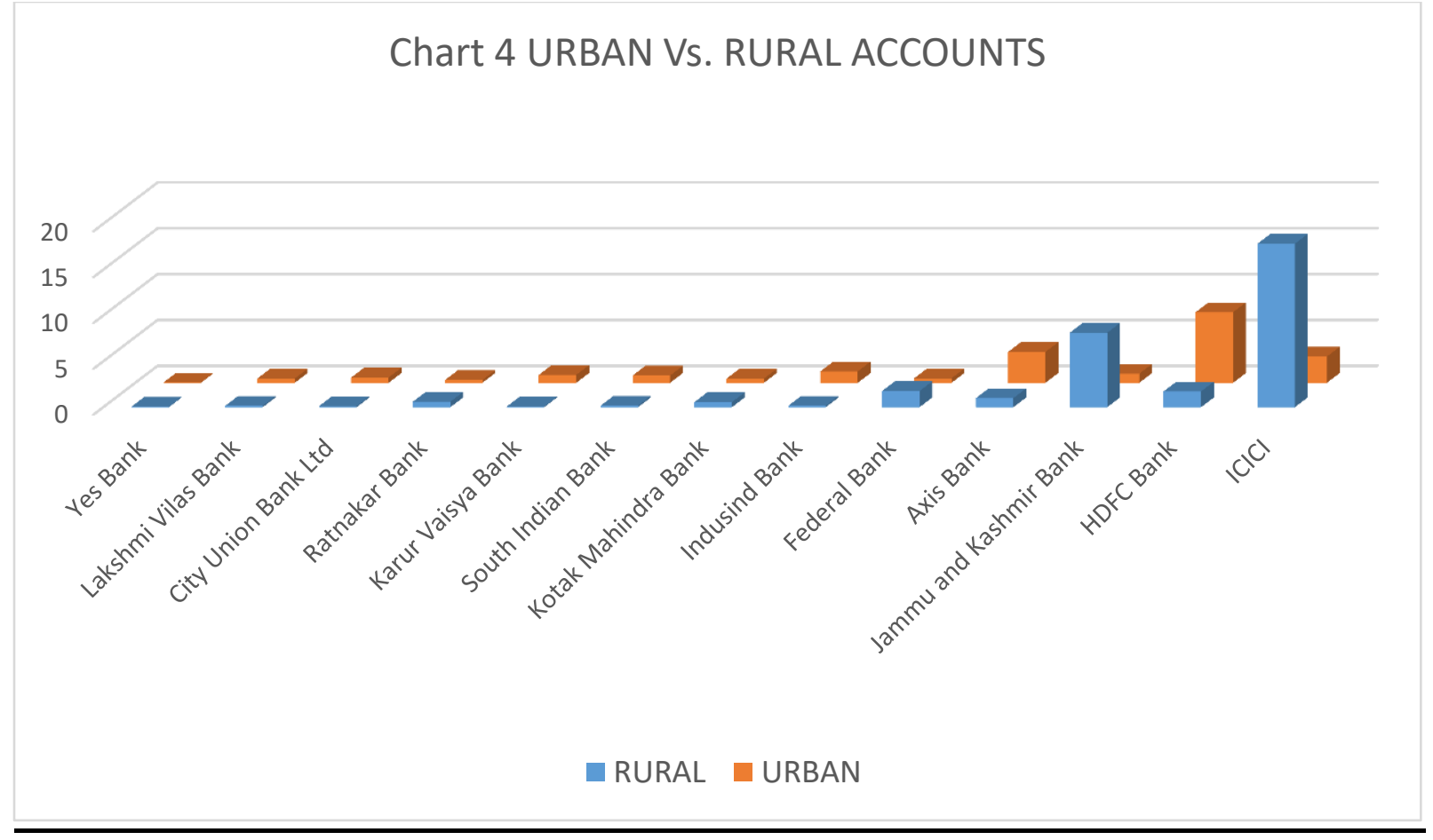

- This graph shows the distribution of urban and rural accounts opened by various private sector banks in phase-I.

- The banks have been arranged in an increasing account opening across various private sector banks during Phase-I.

- Many banks have opened more urban accounts than rural accounts.

- The best performer is ICICI bank which has opened maximum rural accounts followed by Jammu and Kashmir bank during Phase-I.

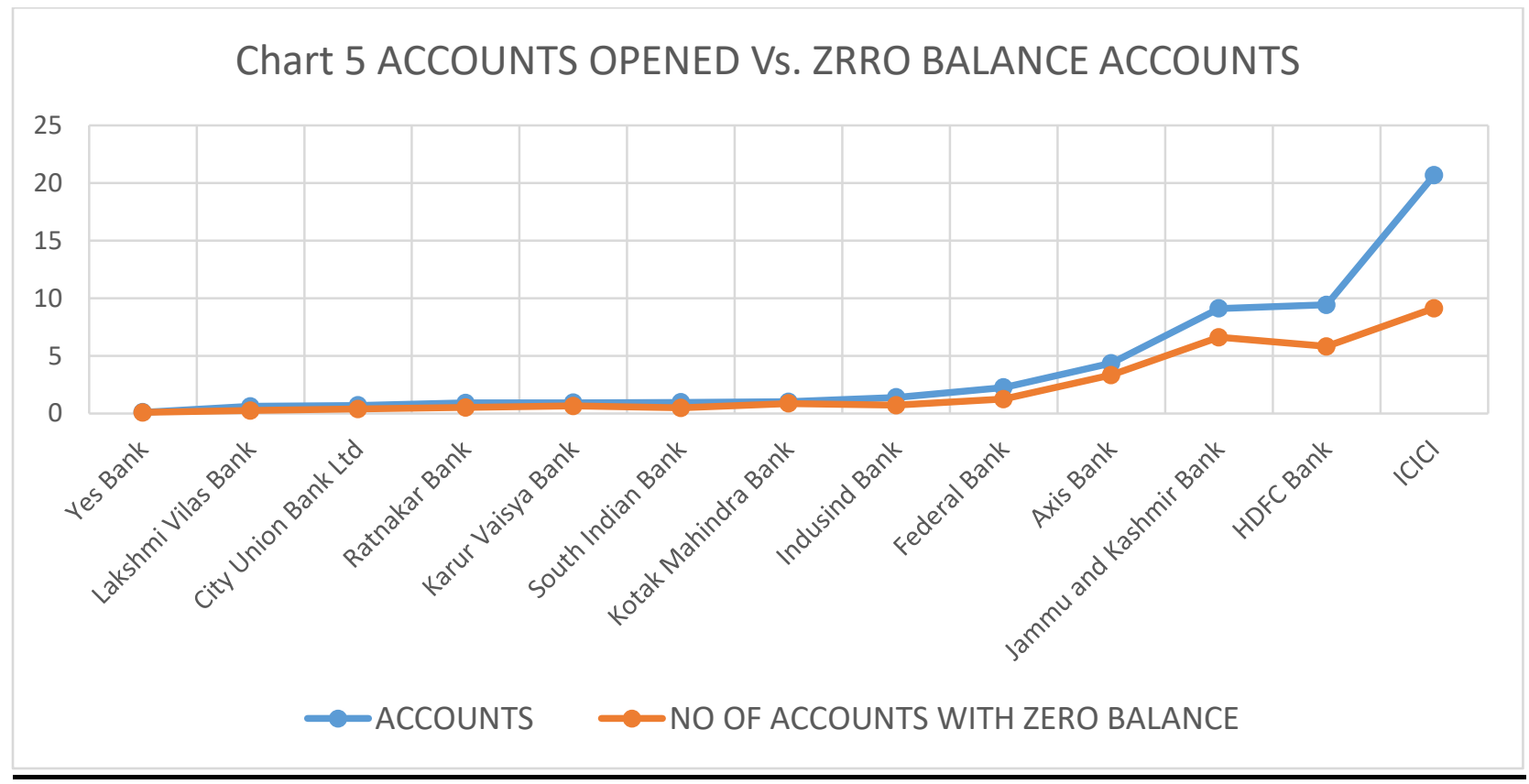


- This graph shows the distribution of accounts opened and the trend of zero balance accounts across various respective banks.

- The banks have been arranged in an increasing account opening across various private sector banks during Phase-I.

- Many private sector banks have not been able to curb the problem of zero balance accounts.

- The best performance have been ICICI bank and closely followed by HDFC bank and Jammu and Kashmir Bank.

\section{Chart 6 BALANCE IN ACCOUNTS}

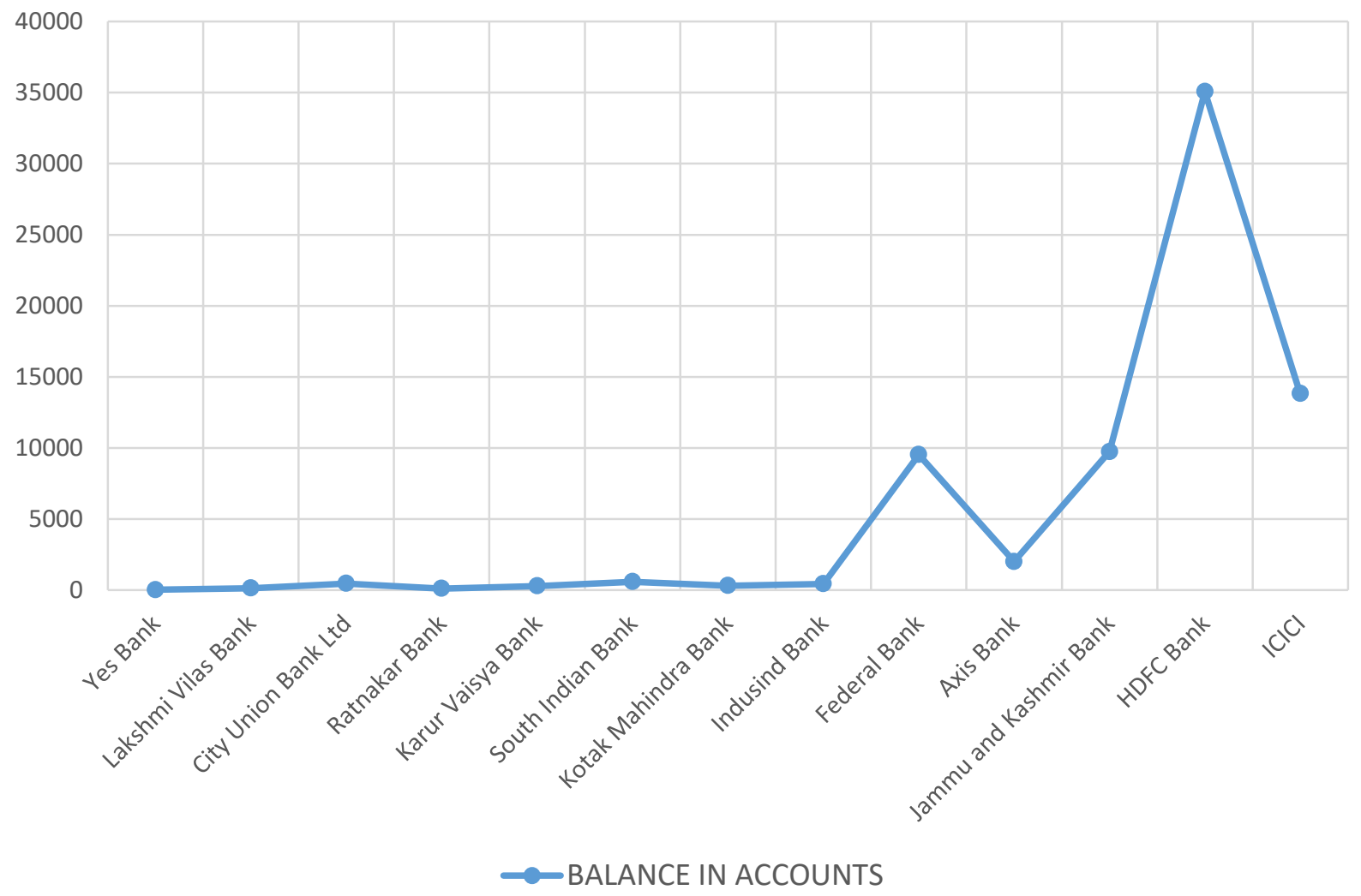

- This graph shows the deposits made across various banks against the account opened during Phase-I.

- There have been an increasing rate of account opening across various private sector banks during Phase-I.

- HDFC bank is the best performing bank in this aspect.

- All the other banks have had minimum deposits.

- It should also be noted that in contrary to the case of public sector banks where the best performer have banks with maximum rural accounts whereas in this case the best performers have been banks with maximum urban accounts. 


\subsection{Regional Rural Banks}

\begin{tabular}{|c|c|c|c|c|c|c|}
\hline $\begin{array}{l}\text { NAME OF } \\
\text { BANK }\end{array}$ & RURAL & URBAN & ACCOUNTS & $\begin{array}{l}\text { RUPAY } \\
\text { DEBIT } \\
\text { CARDS }\end{array}$ & $\begin{array}{c}\text { BALANCE } \\
\text { IN } \\
\text { ACCOUNTS }\end{array}$ & $\begin{array}{c}\text { NO OF } \\
\text { ACCOUNTS } \\
\text { WITH ZERO } \\
\text { BALANCE }\end{array}$ \\
\hline $\begin{array}{l}\text { Punjab \& Sind } \\
\text { Bank }\end{array}$ & 0.09 & 0.02 & 0.11 & 0.11 & 94.78 & 0.02 \\
\hline $\begin{array}{l}\text { State Bank of } \\
\text { Patiala }\end{array}$ & 0.36 & 0.01 & 0.37 & 0.34 & 455 & 0.18 \\
\hline $\begin{array}{l}\text { Jammu and } \\
\text { Kashmir Bank }\end{array}$ & 0.44 & 0.09 & 0.53 & 0 & 377.22 & 0.43 \\
\hline Andhra Bank & 1.22 & 0.09 & 1.31 & 1.22 & 465.68 & 0.87 \\
\hline Dena Bank & 1.71 & 0.09 & 1.81 & 1.67 & 1741 & 1.45 \\
\hline Indian bank & 2.81 & 0.39 & 3.2 & 1.5 & 1275.12 & 2.33 \\
\hline $\begin{array}{l}\text { State Bank of } \\
\text { Mysore }\end{array}$ & 2.66 & 0.78 & 3.44 & 3.01 & 1227.18 & 2.59 \\
\hline $\begin{array}{ll}\text { Bank } & \text { of } \\
\text { Maharashtra } & \\
\end{array}$ & 3.21 & 0.54 & 3.76 & 3.76 & 134.82 & 3.31 \\
\hline Uco Bank & 4.51 & 0.09 & 4.6 & 3.59 & 4516 & 2.86 \\
\hline $\begin{array}{l}\text { Indian Overseas } \\
\text { Bank }\end{array}$ & 4.81 & 0.09 & 4.9 & 0.06 & 3864.26 & 2.45 \\
\hline $\begin{array}{l}\text { State Bank of } \\
\text { Hyderabad }\end{array}$ & 4.47 & 0.76 & 5.23 & 2.3 & 945.49 & 3.9 \\
\hline $\begin{array}{l}\text { Union Bank Of } \\
\text { India }\end{array}$ & 4.43 & 1.1 & 5.53 & 2.99 & 3196.13 & 3.67 \\
\hline Allahabad Bank & 5.22 & 1.11 & 6.33 & 6.16 & 1476.21 & 4.96 \\
\hline Canara Bank & 4.48 & 2.9 & 7.38 & 7.18 & 11522.84 & 2.69 \\
\hline $\begin{array}{l}\text { State Bank of } \\
\text { Bikaner and } \\
\text { Jaipur }\end{array}$ & 7.75 & 0.24 & 7.98 & 7.19 & 7124.24 & 7.05 \\
\hline Syndicate Bank & 9.72 & 2.87 & 12.6 & 11.32 & 12980.09 & 8.39 \\
\hline Bank Of India & 13.23 & 3.74 & 16.97 & 16.46 & 1809 & 15.64 \\
\hline Bank of Baroda & 14.59 & 4.5 & 19.09 & 17.2 & 12407 & 15.03 \\
\hline $\begin{array}{l}\text { Punjab National } \\
\text { Bank }\end{array}$ & 17.49 & 3.02 & 20.51 & 5.61 & 27346.24 & 13.59 \\
\hline $\begin{array}{l}\text { United Bank Of } \\
\text { India }\end{array}$ & 24.8 & 0.45 & 25.25 & 19.06 & 17757.19 & 16.9 \\
\hline $\begin{array}{l}\text { Central bank of } \\
\text { India }\end{array}$ & 21.36 & 4.01 & 25.37 & 23.6 & 27563.59 & 20.78 \\
\hline $\begin{array}{ll}\text { State Bank of } \\
\text { India }\end{array}$ & 35.52 & 6.08 & 41.6 & 15.35 & 21669 & 30.28 \\
\hline Total & 184.88 & 32.97 & 217.87 & 149.68 & 159948.08 & 159.37 \\
\hline
\end{tabular}




\section{Chart 7 URBAN Vs. RURAL ACCOUNTS}

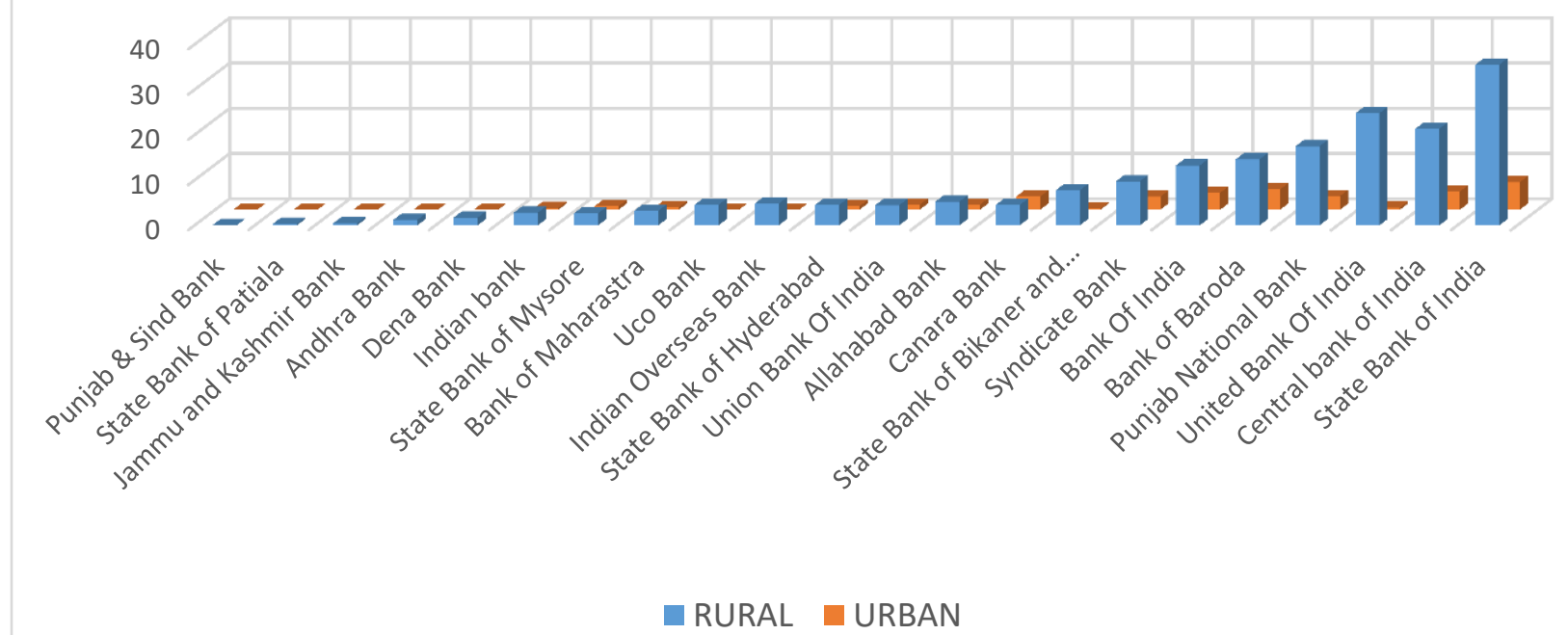

- This graph shows the distribution of urban and rural accounts opened by various Regional Rural banks in phase-I.

- The banks have been arranged in an increasing account opening across various Regional Rural banks during Phase-I.

- All the banks have opened more rural accounts than urban accounts.

- The best performer is State Bank of India (SBI) which has the maximum coverage all over India.

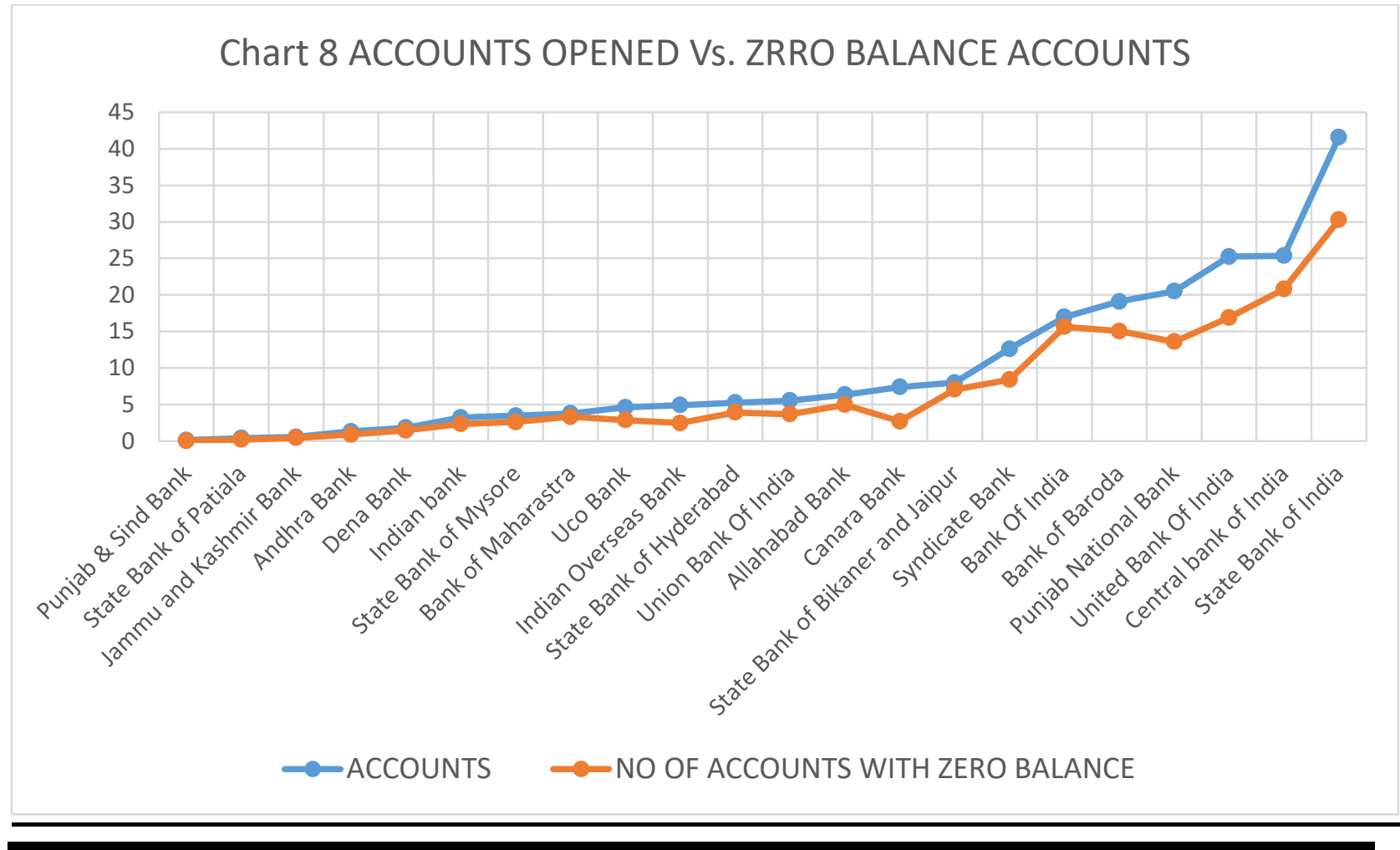


- This graph shows the distribution of accounts opened and the trend of zero balance accounts across various respective banks.

- The banks have been arranged in an increasing account opening across various Regional Rural banks during Phase-I.

- Canara bank have been the most successful bank in curbing the problem of zero balance accounts because of their proactive measures of interacting with various Panchayat and roping in various NGO's into the program, which has resulted for being a success story in PMJDY mission.

- Most banks have not been able to curb the problem of zero balance accounts.

\section{Chart 9 BALANCE IN ACCOUNTS}

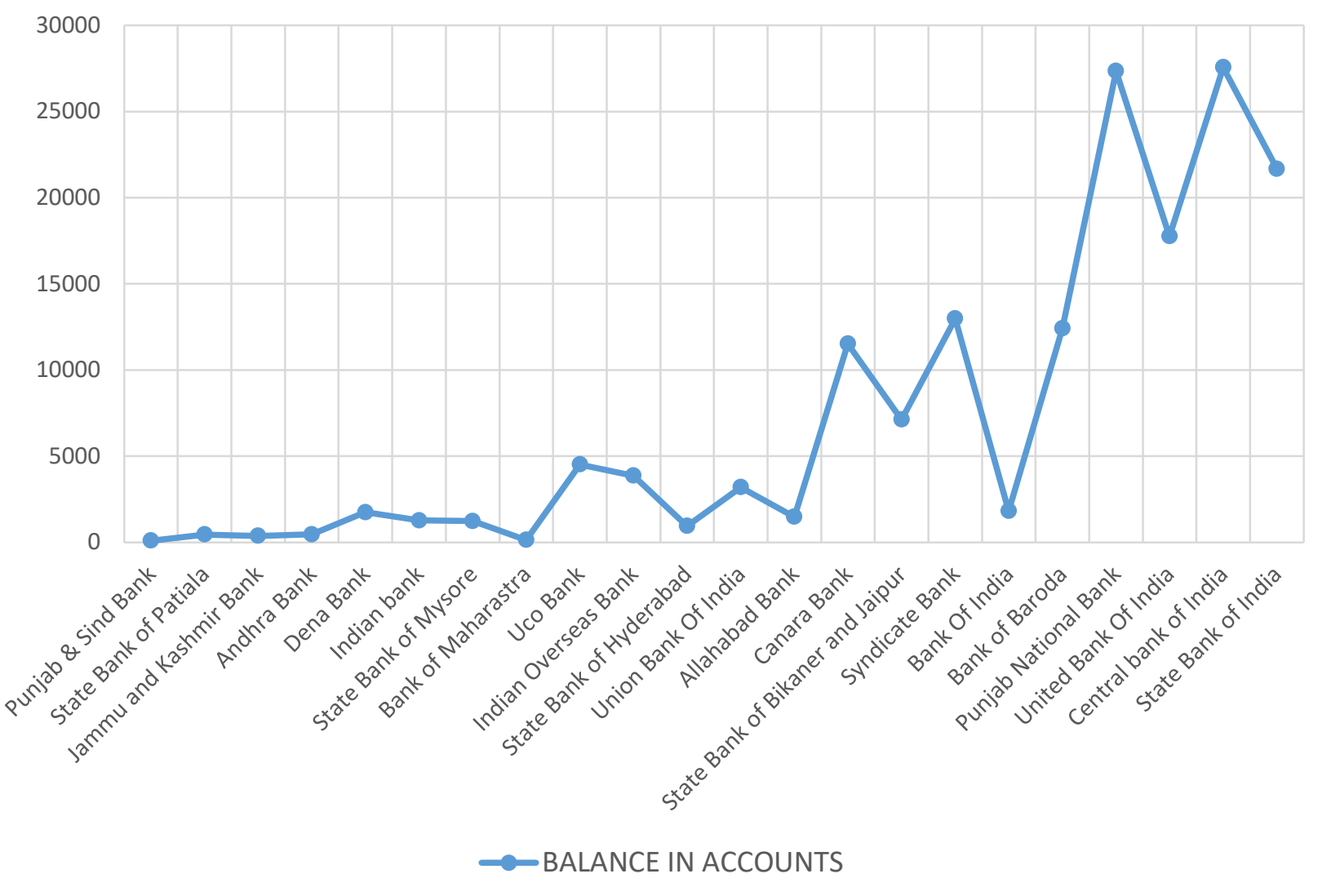

- This graph shows the deposits made across various banks against the account opened during Phase-I.

- The banks have been arranged in an increasing account opening across various Regional Rural banks during Phase-I.

- Central Bank of India is the best performing bank in this aspect closely followed by Punjab National Bank and State Bank of India.

- Canara bank with its proactive measures of reducing the zero balance accounts have been able to have high deposits, whereas even if SBI had maximum account opening it has not been able to have maximum deposits. 
- Even though SBI had maximum account opening it still hasn't been able to have maximum deposits.

\section{Findings}

- Among public sector banks best performer is State Bank of India (SBI) which has the maximum coverage all over India. Moreover It is also noted that the banks that have been the least performers are basically new banks or banks which have less market coverage.

- Canara bank have been the most successful bank in curbing the problem of zero balance accounts because of their proactive measures of interacting with various Panchayat and roping in various NGO's into the program, which has resulted for being a success story in PMJDY mission.

- Among the private sector banks the best performer is ICICI bank which has opened maximum rural accounts followed by Jammu and Kashmir bank during Phase-I.

\section{Conclusion}

Reserve bank of India announced and launched many more schemes in banking sector. Banking sector is one of the emerging ventures and blood of financial inclusion. Last five years ago RBI launched no frills accounts but this scheme did not cover all the people and had not achieved for banking sector. Present day's Indian Prime Minister Narendra Modi launched Pradhan Mantri Jan Dhan Yojana scheme to totally contribute to all the income level people willingly and to make them continuously travel to banking sector. Pradhan Mantri Jan Dhan Yojana scheme is fully helpful to rural and urban area people in getting directly government financial services. This study highlights commercial bank's performance on Pradhan Mantri Jan Dhan Yojana. Hence, it is concludes that, the PMJDY scheme has created an impressive result in the banking sector with regard to eradication of financial untouchability in the country. Mere opening of accounts may not fulfill the aim of the scheme, but there should be continuous operation of bank accounts to give the real success of the scheme.

\section{References}

[1] Aishwarya Sigh, Manoj Sharma \& Mukhes Sadana; „, assessing the most ambitious public financial inclusion drive in history, Microsave India focus note \#114, February 2015

[2] Arundati Bhattacharya, The Journal of Indian Institute of Banking \& Finance, July-September 2015 Banking on Change: Breaking the Barriers to Financial Inclusion, Barclays bank, 2012

[3] Artta Bandhu Jena (2015). "The Pradhan Mantri Jan Dhan Yojana - A Forward Journey towards Financial Inclusion", TRANS Asian Research Journals. Vol.4, Issue.4.

[4] Barhate G. H. and Jagtap V. R., (2014), Pradhan Mantri Jan-Dhan Yojana: National Mission on Financial Inclusion, International Journal of Applied Research, Vol. 4, No. 12, pp.340-342.

[5] Gitte Madhukar, „, PMJDY: national mission on financial inclusion in India ${ }^{e e}$, TMRJ, 2015

[6] Paramasivan C and Kamaraj R (2015) "Commercial Bank's Performance On Pradhan Mantri Jan Dhan Yojana.", International Journal Of Scientific Research And Education, Volume 3, Issue 6, Pages-3595-3603, June-2015, ISSN (e): 2321-7545.

[7] Paramasivan.C and Ganeshkumar.V (2013), "Overview of Financial Inclusion in India", International Journal of Management \& Development Studies, Vol.2, Issue.3, pp45-49. 
[8] Rajanikanta Khuntia (2014) "Pradhan Mantri Jan Dhan Yojana (PMJDY): A New Drive towards Financial Inclusion in India”, Zenith International Journal of Business Economics \& Management Research, Vol.4, Issue.11, pp10-20.

[9] Shetty. S., and Deokar, B. K. (2014). "Financial Inclusion Differences between the Government and RBI?, Economic \& Political Weekly, Vol.49(35), pp12-15.

[10] Singh, A.S., Venkataramani, B., \& Ambarkhane, D. Social Science Research Network (SSRN), Aug 2014

[11] Sinha A; "financial inclusion and UCBs", Economic development in India, volume 171, 2013.

\section{About Author}

Prof. Trilok Nath Shukla is Vice Principal and Associate Professor in the area of Finance, HR, Business statistics and Operation Management at Bhartiya Vidya Bhavan, Bhubneswar. His academic qualifications include M.Sc from IIT, Roorkee, MBA, MBF, LLB, PG Diploma in Labour Law and CFA-I. Prof. Shukla has more than 20 years of experience i.e. more than 16 years of Industrial experience \& 8 years of experience in the field of Academics. Before joining Bhartiya Vidya Bhavan he was working as country head and chief operating officer (COO) in a logistic company. As far as industrial experience is concerned he has worked in diversified sectors like mining, information technology, software's and logistics for more than 16 years.

*Corresponding author.

E-mail address: shuklatrilok@yahoo.com 